\title{
Radioactivity of Tobacco Leaves and Radiation Dose Induced from Smoking
}

\section{Constantin Papastefanou}

Aristotle University of Thessaloniki, Atomic and Nuclear Physics Laboratory, Thessaloniki 54124, Greece; E-mail: papastefanou@physics.auth.gr

Received: 21 November 2008 / Accepted: 20 January 2009 / Published: 5 February 2009

\begin{abstract}
The radioactivity in tobacco leaves collected from 15 different regions of Greece and before cigarette production was studied in order to find out any association between the root uptake of radionuclides from soil ground by the tobacco plants and the effective dose induced to smokers from cigarette tobacco due to the naturally occurring primordial radionuclides, such as ${ }^{226} \mathrm{Ra}$ and ${ }^{210} \mathrm{~Pb}$ of the uranium series and ${ }^{228} \mathrm{Ra}$ of the thorium series and/or man-made radionuclides, such as ${ }^{137} \mathrm{Cs}$ of Chernobyl origin. Gammaray spectrometry was applied using Ge planar and coaxial type detectors of high resolution and high efficiency. It was concluded that the activities of the radioisotopes of radium, ${ }^{226} \mathrm{Ra}$ and ${ }^{228} \mathrm{Ra}$ in the tobacco leaves reflected their origin from the soil by root uptake rather than fertilizers used in the cultivation of tobacco plants. Lead-210 originated from the air and was deposited onto the tobacco leaves and trapped by the trichomes. Potassium40 in the tobacco leaves was due to root uptake either from soil or from fertilizer. The cesium radioisotopes ${ }^{137} \mathrm{Cs}$ and ${ }^{134} \mathrm{Cs}$ in tobacco leaves were due to root uptake and not due to deposition onto the leaf foliage as they still remained in soil four years after the Chernobyl reactor accident, but were absent from the atmosphere because of the rain washout (precipitation) and gravitational settling. The annual effective dose due to inhalation for adults (smokers) for ${ }^{226} \mathrm{Ra}$ varied from 42.5 to $178.6 \mu \mathrm{Sv} / \mathrm{y}$ (average 79.7 $\mu \mathrm{Sv} / \mathrm{y}$ ), while for ${ }^{228} \mathrm{Ra}$ from 19.3 to $116.0 \mu \mathrm{Sv} / \mathrm{y}$ (average $67.1 \mu \mathrm{Sv} / \mathrm{y}$ ) and for ${ }^{210} \mathrm{~Pb}$ from 47.0 to $134.9 \mu \mathrm{Sv} / \mathrm{y}$ (average $104.7 \mu \mathrm{Sv} / \mathrm{y}$ ), that is the same order of magnitude for each radionuclide. The sum of the effective doses of the three radionuclides varied from 151.9 to $401.3 \mu \mathrm{Sv} / \mathrm{y}$ (average $251.5 \mu \mathrm{Sv} / \mathrm{y}$ ). The annual effective dose from ${ }^{137} \mathrm{Cs}$ of Chernobyl origin was three orders of magnitude lower as it varied from 70.4 to $410.4 \mathrm{nSv} / \mathrm{y}$ (average $199.3 \mathrm{nSv} / \mathrm{y}$ ).
\end{abstract}

Keywords: Radioactivity; tobacco leaves; radiation dose; smoking. 


\section{Introduction}

Naturally occurring primordial radionuclides of the uranium-radium series, such as ${ }^{210} \mathrm{~Pb}$ and ${ }^{210} \mathrm{Po}$ have long been associated with tobacco plants [1]. Tso et al. (1966) [2] stated that the principal mechanism of incorporation involves root uptake from soil and phosphate fertilizers. Francis et al. (1968) [3] suggested that the deposition of ${ }^{210} \mathrm{~Pb}$ by rainfall is the principal mechanism of ${ }^{210} \mathrm{~Pb}$ entry in plants. The properties and distribution of trichomes (hairs) on tobacco leaf surfaces suggest that they are effective collectors of small Aitken (nuclei) particles $(<0.1 \mu \mathrm{m}$ diameter) by means of diffusive deposition due to Brownian motion of the particles $[1,4,5]$. As about $85 \%$ of tobacco trichomes have glandular heads coated with a sticky exudates mixture of organic compounds, trichomes may retain the small atmospheric particles which are deposited on the glandular heads throughout the period of plant growth.

So, ${ }^{226} \mathrm{Ra}\left({ }^{238} \mathrm{U}\right.$ - series $),{ }^{228} \mathrm{Ra}\left({ }^{232} \mathrm{Th}\right.$-series $)$ and ${ }^{40} \mathrm{~K}$ of the naturally occurring primordial radionuclides which are abundant in soil and in most fertilizers (uranium-238 is associated with phosphate fertilizers [6]) follow root uptake, whereas airborne ${ }^{210} \mathrm{~Pb}$, a long-lived $\left(\mathrm{T}_{1 / 2}=22.3 \mathrm{y}\right)$ decay product of radon-222, resides on particles $<0.3, \mu \mathrm{m}$ diameter. Papastefanou and Bondietti [7] reported activity median aerodynamic diameters, AMADs for ${ }^{210} \mathrm{~Pb}$ associated with aerosol particles ranging from 0.28 to $0.49 \mu \mathrm{m}$, averaging $0.37 \mu \mathrm{m}$, and is captured on tobacco trichomes.

Cesium-137 and -134 of Chernobyl reactor accident origin, followed both routes, that is, during May 1986 when tobacco plants were planted, both radionuclides were in high concentration in air (1.95 and $0.98 \mathrm{~Bq} \mathrm{~m}^{-3}$, respectively [8]) and these radionuclides were deposited onto the plant leaves and captured on tobacco trichomes. In the years which followed, cesium and all fallout radionuclides after dry and even wet deposition onto the ground were mixed and migrated in the soil to deeper layers below the ground surface, suggesting root uptake.

The issue of radioactivity in tobacco smoke has received much attention in the scientific press and, increasingly, in the medical press [9]. Besides this, Martell and Sweder [10] reported that radon decay products naturally found in the environment are altered when they pass through burning cigarettes into mainstream smoke. Martell [11] stated that the cumulative alpha-, beta- and gamma-radiation dose, particularly that from alpha radiation, from inhaled radionuclides deposited in small volumes of bronchial tissue may be an important factor in the initiation of bronchial (lung) cancer in smokers. The smokers are subjected to alphas radiation in the bronchial epithelium from three sources: (1) from indoor radon and thoron decay products inhaled between cigarettes, (2) from ${ }^{214} \mathrm{Po},{ }^{212} \mathrm{Po}$ and ${ }^{212} \mathrm{Bi}$ in large mainstream smoke particles and (3) from ${ }^{210} \mathrm{Po}$ which grows from decay of ${ }^{210} \mathrm{~Pb}$-enriched particles that persist at bronchial bifurcations [12].

Radford Jr and Hunt [13] at Harvard School of Public Health (Boston, MA,) reported that for an individual smoking two packages of cigarettes a day, the radiation dose to bronchial epithelium from

${ }^{210} \mathrm{Po}$ inhaled in cigarette smoke probably is at least seven times that from background sources, in localized areas may be up to $10 \mathrm{~Sv}$ (1000 rem) or more in $25 \mathrm{y}$. Besides, Winters and Di Franza [14] at the University of Massachusetts (Boston, MA) much later reported that in a person smoking one and a half packs of cigarettes (i.e. 30 cigarettes) per day, the radiation dose to the bronchial epithelium in areas of bifurcation is $80 \mathrm{mSv} \mathrm{y}^{-1}(8,000 \mathrm{mrem})$ - the equivalent of the dose to the skin from $300 \mathrm{X}$-ray 
films of the chest per year. This figure was comparable with total-body exposure to natural background radiation containing $0.8 \mathrm{mSv} \mathrm{y}^{-1}(80 \mathrm{mrem})$ in someone living in the Boston area.

Takizawa et al. [15] reported that the range of ${ }^{210} \mathrm{Po}$ contained in the tobacco grands in Japan varied from 13.0 to $20.1 \mathrm{~Bq} \mathrm{~kg}^{-1}$ (mean $15.4 \mathrm{~Bq} \mathrm{~kg}^{-1}$ ), $50 \%$ of ${ }^{210} \mathrm{Po}$ present in tobacco was transferred into the smoke and the other $50 \%$ remained in the ash and butt. One pack-a-day smoker inhaled $24 \mathrm{mBq}$ $\mathrm{d}^{-1}$ of ${ }^{210} \mathrm{Po}$ through smoking and the annual inhalation was $8.8 \mathrm{~Bq}$. Peres and Hiromoto [16] reported that ${ }^{210} \mathrm{Po}$ in (dry) tobacco in Brazil ranged from 10.9 to $27.4 \mathrm{~Bq} \mathrm{~kg}^{-1}$ and ${ }^{210} \mathrm{~Pb}$ from 11.9 to $30.2 \mathrm{~Bq}$ $\mathrm{kg}^{-1}$. The collective committed effective dose resulting from the use of cigarettes produced in Brazil per year was estimated to be $1.5 \times 10^{4}$ man Sv, considering an annual production of $5 \times 10^{8} \mathrm{~kg}$ of cigarettes in Brazil and the committed effective dose of $0.16 \mathrm{mSv} \mathrm{y}^{-1}$ of cigarette smoking.

Colangelo et al. [17] reported ${ }^{210} \mathrm{Po}$ in tobacco in Argentina ranged from 10 to $80 \mathrm{~Bq} \mathrm{~kg}^{-1}$ and the lung dose due to the use of tobacco varied from 75 to $600 \mu \mathrm{Sv} \mathrm{y}^{-1}$. Khater [18] reported that the range of ${ }^{210} \mathrm{Po}$ in cigarette tobacco in Egypt ranged from 9.7 to $22.5 \mathrm{mBq}$ per cigarette (average $16.6 \mathrm{mBq}$ per cigarette). The average percentages of ${ }^{210} \mathrm{Po}$ content in fresh tobacco plus wrapping paper that were recorded by post-smoking filters, ash and smoke were 4.6, 20.7 and 74.7, respectively. Cigarette smokers, who are smoking one pack (20 cigarettes) per day, are inhaling on average $123 \mathrm{mBq} \mathrm{d}^{-1}$ of ${ }^{210} \mathrm{Po}$ and ${ }^{210} \mathrm{~Pb}$ each. The mean values of the annual effective dose for smokers (one pack per day) were estimated to be 193 and $251 \mu \mathrm{Sv} \mathrm{y}^{-1}$ from ${ }^{210} \mathrm{Po}$ and ${ }^{210} \mathrm{~Pb}$, respectively.

Approximately $10 \mathrm{~L} \mathrm{~d}^{-1}$ is inhaled through 40 cigarettes-this is about $1 / 2000$ of the amount of air usually breathed per day $\left(20 \mathrm{~m}^{3} \mathrm{~d}^{-1}[10,19]\right.$. Published radiochemical data for inhaled mainstream smoke showed on average ${ }^{210} \mathrm{Po}$ content of $1.33 \mathrm{mBq}(0.036 \mathrm{pCi})$ per cigarette or $96.2 \mathrm{~Bq} \mathrm{~kg}^{-1} \mathrm{smoke}$ (2.6 $\mathrm{pCi}{ }^{210}$ Po per g smoke) [20], with a ${ }^{210} \mathrm{~Pb}:{ }^{210} \mathrm{Po}$ ratio of $0.66 \pm 0.23$ [21].

This paper reports data on the radioactivity of tobacco leaves after the collection from tobacco fields before cigarette production in order to find any association in the uptake of the naturally occurring radionuclides and of cesium radioisotopes of Chernobyl origin, and to estimate the effective dose from cigarette tobacco as the cumulative $\alpha$-, $\beta$ - and $\gamma$-radiation dose, particularly that from $\alpha$ radiation, from inhaled radionuclides deposited in small volumes of bronchial tissue may be an important factor in the initiation of bronchial (lung) cancer in smokers [11].

\section{Materials and Methods}

Seventeen different samples of tobacco leaves produced in the year 1990 at different locations in Greece (Figure 1, Table 1) were examined a year later for radioactivity using $\gamma$-ray spectrometry. The spectrometric system consisted of two different high-purity Germanium low-background detectors. One planar Ge detector of active area $2000 \mathrm{~mm}^{2}$, thickness $20 \mathrm{~mm}$, Be window $0.6 \mathrm{~mm}$ and energy resolution (FWHM) $400 \mathrm{eV}$ for $5.9 \mathrm{keV} \gamma$-rays $\left({ }^{55} \mathrm{Fe}\right)$ and $700 \mathrm{eV}$ for $122 \mathrm{keV} \gamma$ - rays $\left({ }^{57} \mathrm{Co}\right)$, was appropriate for $\gamma$-rays ranging from 5 to $186 \mathrm{keV}$ for determination of ${ }^{210} \mathrm{~Pb}(47 \mathrm{keV}),{ }^{226} \mathrm{Ra}(186 \mathrm{keV})$ and ${ }^{238} \mathrm{U}$ via its decay product ${ }^{234} \mathrm{Th}$ with 63 and $93 \mathrm{keV} \gamma$-rays. A second coaxial Ge detector (p-type), crystal size $155 \mathrm{cc}$, resolution (FWHM) $1.9 \mathrm{keV}$ at $1.33 \mathrm{MeV}\left({ }^{60} \mathrm{Co}\right)$ and $900 \mathrm{eV}$ at $122 \mathrm{keV}\left({ }^{57} \mathrm{Co}\right)$, peak-to-Compton ratio 55:1 and efficiency $42 \%$, was appropriate for $\gamma$-rays ranging from 240 to 2614 $\mathrm{keV}$ for determination of ${ }^{226} \mathrm{Ra}$ via its decay products ${ }^{214} \mathrm{~Pb}$ and ${ }^{214} \mathrm{Bi},{ }^{232} \mathrm{Th}$ via its decay products ${ }^{228} \mathrm{Th},{ }^{228} \mathrm{Ac}$ and ${ }^{228} \mathrm{Ra},{ }^{40} \mathrm{~K}(1460 \mathrm{keV}),{ }^{137} \mathrm{Cs}(662 \mathrm{keV})$ and ${ }^{134} \mathrm{Cs}(605 \mathrm{keV})$. 
Figure 1. A map of Greece showing the sampling locations of the tobacco leaves (Table 1).

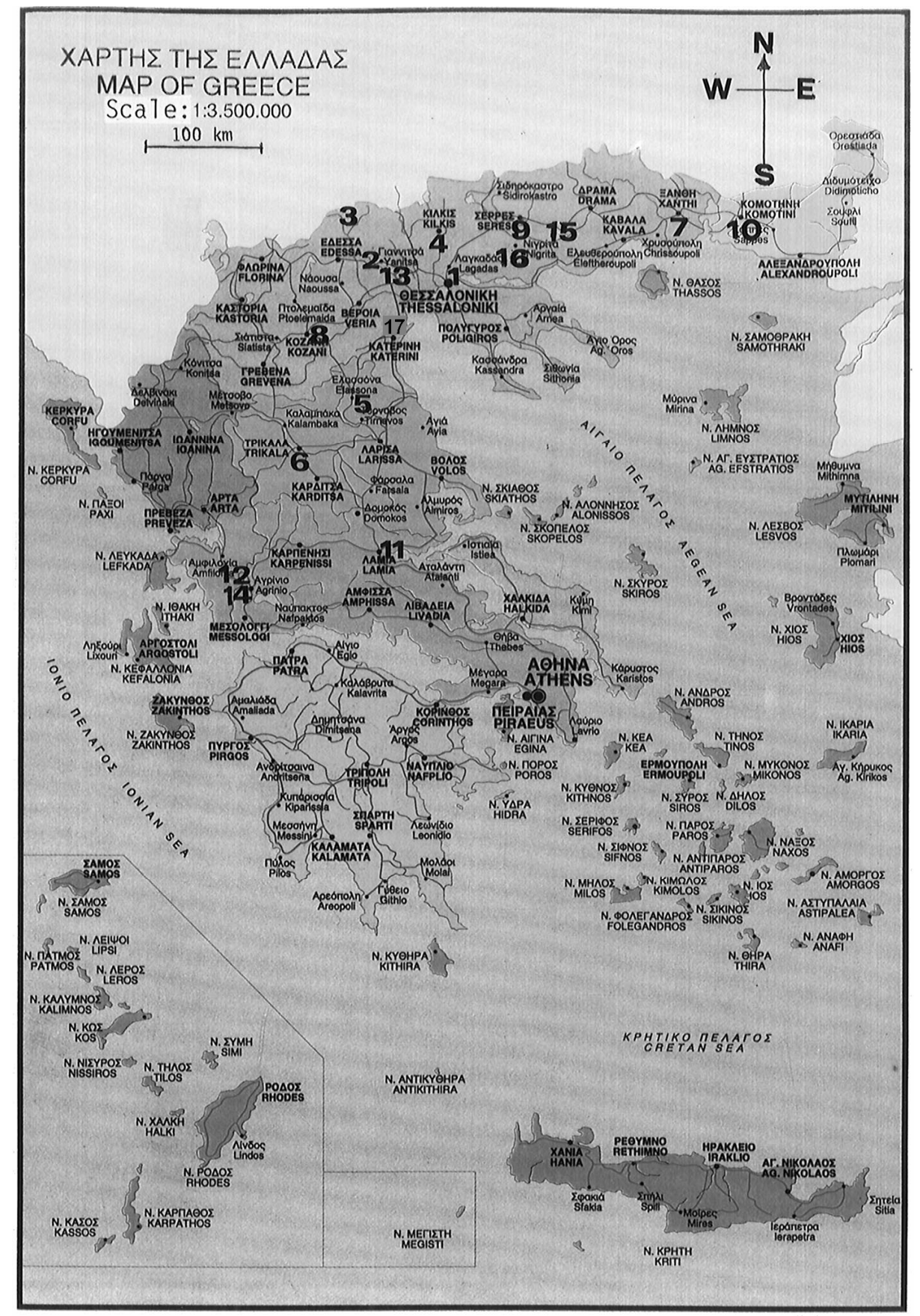

The samples were dried before radioactivity measurement for 3-4 days at a temperature of $30^{\circ} \mathrm{C}$ to avoid any moisture adsorption. After that, the samples were cut into very small pieces using a blender and were mixed with active charcoal and then sealed appropriately for about one month to reduce leaching and to attain radioactive equilibrium between radon and thoron decay products [22], as eight half-lives of ${ }^{222} \mathrm{Rn}\left(\mathrm{T}_{1 / 2}=3.82 \mathrm{~d}\right)$, the decay product of ${ }^{226} \mathrm{Ra}$ and precursor of ${ }^{214} \mathrm{~Pb}$ and ${ }^{214} \mathrm{Bi}$, correspond to 1 month. About eight half-lives of ${ }^{224} \mathrm{Ra}\left(\mathrm{T}_{1 / 2}=3.66 \mathrm{~d}\right)$, the decay product of ${ }^{228} \mathrm{Ra}$, are also 1 month. 
The samples were measured for radioactivity in two geometries, that is, in a standard geometry $40 \mathrm{~g}$ plastic can of $6 \mathrm{~cm}$ diameter and a Marinelli beaker of $1 \mathrm{~L}$ (volume). The overall efficiency of the counting system was known to an accuracy of better than $5 \%$ for the plastic can geometry and about $12 \%$ for the Marinelli beaker. The +- errors in Table 1 are the experimental errors of each measurement. The collecting time was $120,000 \mathrm{~s}$.

Gamma-ray spectra obtained with both HPGe detectors are presented in Figure 2a for the planar detector and Figure $2 \mathrm{~b}$ for the coaxial detector.

Figure 2. Gamma-ray spectrum of tobacco leaves. (a) Gamma photon energies ranging up to $186 \mathrm{keV}$ obtained with planar detector. (b) Gamma photon energies ranging up to $2614 \mathrm{keV}$ obtained with coaxial detector.
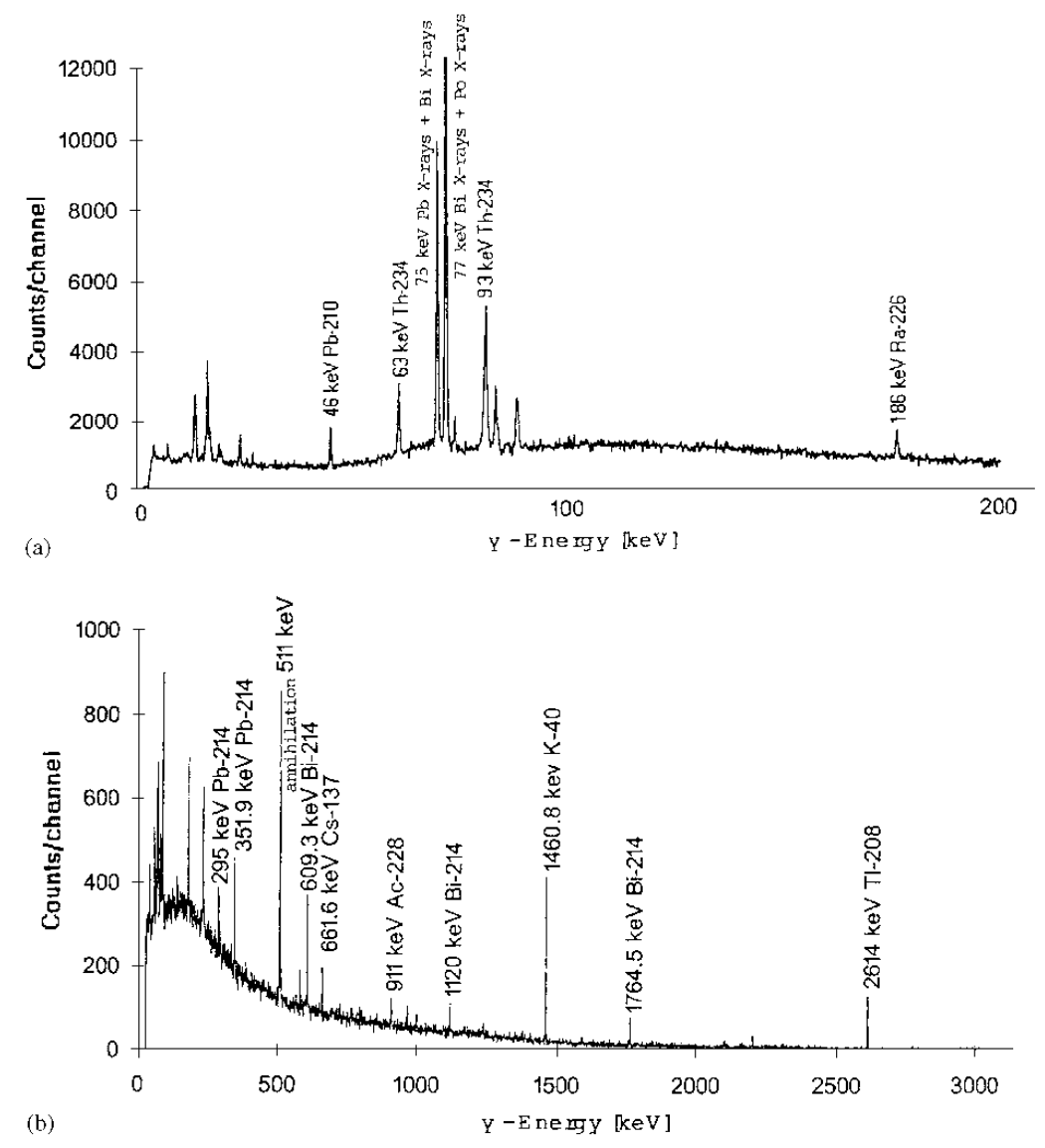

\section{Results and Discussion}

\subsection{Radionuclide Concentrations}

Table 1 presents the concentrations in $\mathrm{Bq} \mathrm{kg}{ }^{-1}$ of ${ }^{226} \mathrm{Ra},{ }^{210} \mathrm{~Pb},{ }^{228} \mathrm{Ra},{ }^{40} \mathrm{~K},{ }^{137} \mathrm{Cs}$ and ${ }^{134} \mathrm{Cs}$ in Greek tobacco leaves produced in 1990, i.e. four years after the Chernobyl reactor accident (26 April 1986).

In the tobacco leaves, ${ }^{226} \mathrm{Ra}$ activity concentrations ranged from 1.80 to $7.57 \mathrm{~Bq} \mathrm{~kg}^{-1}$ (average 3.38 $\mathrm{Bq} \mathrm{kg}^{-1}$ ), while ${ }^{228} \mathrm{Ra}$ activity concentrations ranged from 1.10 to $6.52 \mathrm{~Bq} \mathrm{~kg}^{-1}$ (average $3.83 \mathrm{~Bq} \mathrm{~kg}^{-1}$ ). The results showed that ${ }^{226} \mathrm{Ra}$ and ${ }^{228} \mathrm{Ra}$ concentrations in tobacco leaves were comparable, reflecting their origin in soil by root uptake rather than in fertilizers used for cultivation in the fields. It is known 


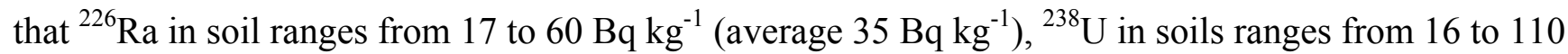
$\mathrm{Bq} \mathrm{kg}^{-1}$ (average $35 \mathrm{~Bq} \mathrm{~kg}^{-1}$ ) and ${ }^{228} \mathrm{Ra}^{232} \mathrm{Th}$ ) in soils ranges from 11 to $64 \mathrm{~Bq} \mathrm{~kg}^{-1}$ (average $30 \mathrm{~Bq} \mathrm{~kg}^{-}$ $\left.{ }^{1}\right)$ [23]. Papastefanou (2001) [6] reported that ${ }^{238} \mathrm{U}$ concentrations in phosphate fertilizers ranged from 312 to $936 \mathrm{~Bq} \mathrm{~kg}^{-1}$ (average $638 \mathrm{~Bq} \mathrm{~kg}^{-1}$ ). Radium-226 concentrations in phosphate fertilizers ranged from 19 to $1129 \mathrm{~Bq} \mathrm{~kg}^{-1}$ (average $418 \mathrm{~Bq} \mathrm{~kg}^{-1}$ ). Thorium-232 concentrations in phosphate fertilizers ranged from 2 to $12 \mathrm{~Bq} \mathrm{~kg}^{-1}$ (average $6 \mathrm{~Bq} \mathrm{~kg}^{-1}$ ).

Table 1. Activity concentrations in tobacco leaves (Bq kg-1).

\begin{tabular}{lccccccc}
\hline No & Lab.No. & ${ }^{\mathbf{2 2 6}} \mathbf{R a}$ & ${ }^{\mathbf{2 1 0}} \mathbf{P b}$ & ${ }^{\mathbf{2 2 8}} \mathbf{R a}$ & ${ }^{\mathbf{4 0}} \mathbf{K}$ & ${ }^{\mathbf{1 3 7}} \mathbf{C s}$ & ${ }^{\mathbf{1 3 4}} \mathbf{C s}$ \\
\hline 1 & TAB-2 & $6 \pm 1$ & $16 \pm 1$ & $5 \pm 1$ & $819 \pm 20$ & $7 \pm 1$ & M.D.A \\
2 & TAB-3 & $2 \pm 1$ & $16 \pm 5$ & $6 \pm 1$ & $897 \pm 21$ & $4 \pm 1$ & M.D.A \\
3 & TAB-4 & $3 \pm 2$ & $17 \pm 5$ & $5 \pm 1$ & $619 \pm 270$ & $6 \pm 1$ & M.D.A. \\
4 & TAB-5 & $4 \pm 1$ & $18 \pm 4$ & $5 \pm 1$ & $825 \pm 20$ & $7 \pm 1$ & M.D.A. \\
5 & TAB-6 & $3 \pm 1$ & $9 \pm 4$ & $5 \pm 1$ & $771 \pm 19$ & $5 \pm 1$ & M.D.A. \\
6 & TAB-7 & $2 \pm 1$ & $6 \pm 4$ & $3 \pm 1$ & $872 \pm 16$ & $6 \pm 1$ & M.D.A. \\
7 & TAB-8 & $8 \pm 1$ & $14 \pm 5$ & $7 \pm 1$ & $967 \pm 22$ & $2 \pm 1$ & M.D.A. \\
8 & TAB-9 & $3 \pm 1$ & $16 \pm 5$ & $3 \pm 1$ & $618 \pm 16$ & $3 \pm 1$ & - \\
9 & TAB-10 & $3 \pm 1$ & $18 \pm 5$ & $5 \pm 1$ & $745 \pm 19$ & $2 \pm 1$ & M.D.A. \\
10 & TAB-11 & $3 \pm 1$ & $14 \pm 4$ & $4 \pm 1$ & $751 \pm 14$ & $3 \pm 1$ & M.D.A. \\
11 & TAB-12 & $2 \pm 1$ & $17 \pm 5$ & $1 \pm 1$ & $756 \pm 20$ & $2 \pm 1$ & M.D.A \\
12 & TAB-13 & $4 \pm 1$ & $8 \pm 5$ & $3 \pm 1$ & $879 \pm 18$ & $2 \pm 1$ & M.D.A. \\
13 & TAB-14 & $3 \pm 1$ & $16 \pm 5$ & $3 \pm 1$ & $2080 \pm 26$ & $2 \pm 1$ & M.D.A. \\
14 & TAB-15 & $2 \pm 2$ & $17 \pm 4$ & $3 \pm 1$ & $1110 \pm 20$ & M.D.A. & M.D.A. \\
15 & TAB-16 & $3 \pm 1$ & $15 \pm 5$ & $4 \pm 1$ & $493 \pm 16$ & $1 \pm 1$ & M.D.A \\
16 & TAB-17 & $3 \pm 1$ & $7 \pm 4$ & $2 \pm 1$ & $273 \pm 13$ & $2 \pm 1$ & M.D.A \\
17 & TAB-18 & $3 \pm 1$ & $17 \pm 4$ & $4 \pm 1$ & $503 \pm 16$ & $4 \pm 1$ & 0.6 \pm 0.2 \\
\hline
\end{tabular}

Lead-210 activity concentrations in the tobacco leaves ranged from 6.34 to $18.2 \mathrm{~Bq} \mathrm{~kg}^{-1}$ (average 14.12 $\mathrm{Bq} \mathrm{kg}{ }^{-1}$ ). The results showed that ${ }^{210} \mathrm{~Pb}$ concentrations were much higher than those of ${ }^{226} \mathrm{Ra}$, indicating that ${ }^{210} \mathrm{~Pb}$ atoms originating from the air were deposited onto the leaves of the tobacco plants and were trapped by the trichomes. It must be noted that ${ }^{210} \mathrm{Po}$, an $\alpha$-emitter $\left(\mathrm{T}_{1 / 2}=138.38 \mathrm{~d}\right)$ and decay product of ${ }^{210} \mathrm{~Pb}$, is a constituent of ambient aerosol particles and must be deposited onto the tobacco leaves and trapped by the trichomes also.

Potassium-40 activity concentrations in the tobacco leaves ranged from 273 to $2080 \mathrm{~Bq} \mathrm{~kg}^{-1}$ (average $823 \mathrm{~Bq} \mathrm{~kg}^{-1}$ ). Two of the seventeen samples (Table 1) showed unusually high activity concentrations of ${ }^{40} \mathrm{~K}$. The results showed that ${ }^{40} \mathrm{~K}$ concentrations were due to root uptake either from soil or from fertilizer. Potassium-40 in soils ranges from 140 to $850 \mathrm{~Bq} \mathrm{~kg}^{-1}$ (average $400 \mathrm{~Bq} \mathrm{~kg}^{-1}$ ) [23] and in phosphate fertilizers from 53 to $6370 \mathrm{~Bq} \mathrm{~kg}^{-1}$ (average $2438 \mathrm{~Bq} \mathrm{~kg}^{-1}$ ) [6].

Cesium-137 activity concentrations in the tobacco leaves ranged from 1.20 to $7.00 \mathrm{~Bq} \mathrm{~kg}^{-1}$ (average $3.40 \mathrm{~Bq} \mathrm{~kg}{ }^{-1}$ ). The results showed that ${ }^{137} \mathrm{Cs}$ concentrations were due to root uptake because ${ }^{137} \mathrm{Cs}$ $\left(T_{1 / 2}=30.17 \mathrm{y}\right)$ still remained in soil four years after the Chernobyl reactor accident [24]. Cesium-137 concentrations in tobacco leaves in 1986, the year of Chernobyl accident, varied between 70 and 180 $\mathrm{Bq} \mathrm{kg}^{-1}$ (average $100 \mathrm{~Bq} \mathrm{~kg}^{-1}$ ). According to fallout radioactivity measurements performed by the Atomic and Nuclear Physics Laboratory, Aristotle University of Thessaloniki for the Ioannou Tobacco 
Industry, at Thessaloniki, Northern Greece, as reported on April 12, 1987 on a special certificate used for dry tobacco export.

\subsection{Effective Dose Estimate}

Assuming $0.82 \mathrm{~g}$ of tobacco per cigarette in Greek cigarettes and a smoker is smoking 30 cigarettes (one and a half packs) per day or $24.6 \mathrm{~g}$ of tobacco per day, then the annual consumption of tobacco by cigarettes is estimated to be $8.985 \mathrm{~kg} \mathrm{y}^{-1}$. Taking into consideration the data of Table 1 for the radionuclide concentrations $\left(\mathrm{Bq} \mathrm{kg}^{-1}\right)$ in tobacco dry leaves, the fraction of the radionuclide activity concentration that is recovered from cigarette tobacco to cigarette smoke is 0.75 (75\%), as on the average, about $75 \%$ of the radioisotope in the cigarette tobacco was contained in the cigarette smoke, which is partially inhaled and deposited in the lung tissues and about $25 \%$ was retained in the cigarette filter and ash [18] and the most recent dose conversion coefficients of the radionuclides $\left(\mathrm{Sb} \mathrm{Bq}^{-1)}\right.$ for the case of inhalation for adults (smokers) as presented in Table 2, then the data of Table 3 are derived for the annual effective dose, $\mathrm{H}_{\mathrm{E}}\left(\mathrm{Sv} \mathrm{y}^{-1}\right)$, due to inhalation for adults (smokers), according to the equation:

$$
\mathrm{H}_{\mathrm{E}}=0.75 \times \mathrm{M}_{\mathrm{T}} \times \mathrm{Ci} \times \mathrm{F}
$$

where $\mathrm{M}_{\mathrm{T}}\left(\mathrm{kg} \mathrm{y}^{-1}\right)$ refers to the annual amount (in mass) of tobacco consumed, $\mathrm{Ci}\left(\mathrm{Bq} \mathrm{kg}^{-1}\right)$ refers to the concentration of the ith radionuclide, and $\mathrm{F}\left(\mathrm{Sv} \mathrm{Bq}^{-1}\right)$ refers to the dose conversion factor [25-28].

Table 2. Dose conversion factors for inhalation for adults.

\begin{tabular}{crc}
\hline Radionuclide & $\mathbf{S v ~ B q}^{-1}$ & Reference \\
\hline${ }^{226} \mathrm{Ra}$ & $3.50 \times 10^{-6}$ & {$[27-28]$} \\
${ }^{228} \mathrm{Ra}$ & $2.60 \times 10^{-6}$ & {$[27-28]$} \\
${ }^{210} \mathrm{~Pb}$ & $1.10 \times 10^{-6}$ & {$[27-28]$} \\
${ }^{210} \mathrm{Po}$ & $3.30 \times 10^{-6}$ & {$[27-28]$} \\
${ }^{137} \mathrm{Cs}$ & $8.70 \times 10^{-9}$ & {$[25-26]$} \\
\hline
\end{tabular}

From the data of Table 3, it is shown that the annual effective dose to ${ }^{226} \mathrm{Ra}$ varied from 42.5 to 178.6 $\mu \mathrm{Sv}^{-1}$ (average $79.7 \mu \mathrm{Sv} \mathrm{y}^{-1}$ ), while for ${ }^{228} \mathrm{Ra}$ from 19.3 to $116.0 \mu \mathrm{Sv} \mathrm{y}^{-1}$ (average $67.1 \mu \mathrm{Sv} \mathrm{y}^{-1}$ ) and for ${ }^{210} \mathrm{~Pb}$ from 47.0 to $134.9 \mu \mathrm{Sv} \mathrm{y}{ }^{-1}$ (average $104.7 \mu \mathrm{Sv} \mathrm{y}^{-1}$ ), that is of the same order of magnitude for each natural radionuclide. The dose from ${ }^{210} \mathrm{Po}\left(\alpha\right.$-emitter), a decay product of ${ }^{210} \mathrm{~Pb}$, should be of the same order of magnitude of the dose due to ${ }^{210} \mathrm{~Pb}$. Holtzman and Ilcewicz (1966) [21] reported that in smokers the ${ }^{210} \mathrm{Po}$ is nearly in radioactive equilibrium with its precursor ${ }^{210} \mathrm{~Pb}$ $\left({ }^{210} \mathrm{Po}:{ }^{210} \mathrm{~Pb}=0.87 \pm 0.10\right)$. The sum of the effective doses of the three natural radionuclides varied from 151.9 to $401.3 \mu \mathrm{Sv} \mathrm{y}{ }^{-1}$ (average $251.5 \mu \mathrm{Sv} \mathrm{y}^{-1}$ ). This dose must be compared with the average worldwide exposure to natural radiation sources $2.4 \mathrm{mSv} \mathrm{y}^{-1}$ and especially the part due to inhalation which is $1.26 \mathrm{mSv} \mathrm{y}^{-1}$ [23].

The annual effective dose due to ${ }^{137} \mathrm{Cs}$ of Chernobyl origin was three orders of magnitude lower. It varied from 70.4 to $410.4 \mathrm{nSv} \mathrm{y}^{-1}$ (average $199.3 \mathrm{nSv} \mathrm{y}^{-1}$ ) and so very little is contributing to the total dose due to inhalation to smokers. Cesium-134, with a relatively short half-life $\left(\mathrm{T}_{1 / 2}=2.6 \mathrm{y}\right)$ was not 
considered in estimating the annual effective dose for its faster decay resulting in activity concentrations mostly below the maximum detectable activity, MDA (Table 1).

Table 3. Annual effective dose of smokers in smoking 30 cigarettes per day.

\begin{tabular}{|c|c|c|c|c|c|}
\hline No. & Lab.No. & $\begin{array}{c}{ }^{226} \mathrm{Ra} \\
\left(\mu \mathrm{Sv} \mathrm{y}^{-1}\right)\end{array}$ & $\begin{array}{c}{ }^{210} \mathrm{~Pb} \\
\left(\mu \mathrm{Sv} \mathrm{y}^{-1}\right)\end{array}$ & $\begin{array}{c}{ }^{228} \mathrm{Ra} \\
\left(\mu \mathrm{Sv} \mathrm{y}^{-1}\right)\end{array}$ & $\begin{array}{c}{ }^{137} \mathrm{Cs} \\
\left(\mathrm{nSv} \mathrm{y}^{-1}\right) \\
\end{array}$ \\
\hline 1 & TAB-2 & 146.47 & 121.57 & 89.36 & 410.39 \\
\hline 2 & TAB-3 & 50.24 & 114.89 & 98.47 & 235.68 \\
\hline 3 & TAB-4 & 74.06 & 122.31 & 83.93 & 367.01 \\
\hline 4 & TAB-5 & 86.33 & 134.91 & 88.83 & 410.39 \\
\hline 5 & TAB-6 & 70.28 & 63.90 & 84.28 & 275.55 \\
\hline 6 & TAB-7 & 55.67 & 47.00 & 53.61 & 371.69 \\
\hline 7 & TAB-8 & 178.55 & 106.74 & 115.99 & 99.67 \\
\hline 8 & TAB-9 & 76.89 & 119.34 & 55.01 & 175.88 \\
\hline 9 & TAB-10 & 74.77 & 129.72 & 81.12 & 93.80 \\
\hline 10 & TAB-11 & 65.89 & 104.52 & 72.19 & 191.12 \\
\hline 11 & TAB-12 & 42.46 & 127.50 & 19.28 & 99.67 \\
\hline 12 & TAB-13 & 86.80 & 56.48 & 52.74 & 123.12 \\
\hline 13 & TAB-14 & 73.59 & 119.34 & 46.96 & 124.29 \\
\hline 14 & TAB-15 & 51.42 & 128.98 & 51.34 & - \\
\hline 15 & TAB-16 & 77.36 & 111.93 & 61.67 & 70.35 \\
\hline 16 & TAB-17 & 73.12 & 47.96 & 30.84 & 89.70 \\
\hline 17 & TAB-18 & 74.06 & 122.31 & 61.15 & 249.17 \\
\hline
\end{tabular}

Dose induced from ${ }^{40} \mathrm{~K}$ was not considered, although its concentration in all samples of tobacco leaves was of the same level of this radionuclide in the soil ground except that of the samples No. 13 and 14 (Table 1). Potassium is one of the most abundant element in every environmental sample. Potassium-40 is the predominant radioactive component in normal food and human tissue and distributes throughout the human body [19].

From the literature, it is seen that the dose estimated for smokers was considered only for ${ }^{210} \operatorname{Po}(\alpha-$ emitter) and its precursor ${ }^{210} \mathrm{~Pb}(\beta$-, $\gamma$-emitter). No consideration was taken on the radioisotopes of radium, i.e. ${ }^{226} \mathrm{Ra}$ of the uranium series and ${ }^{228} \mathrm{Ra}$ of the thorium series, although the dose for inhalation from each of them was shown to be of the same order of magnitude with that of ${ }^{210} \mathrm{~Pb}$ and of course, of ${ }^{210} \mathrm{Po}[27-28]$.

For the dose due to ${ }^{137} \mathrm{Cs}$ of Chernobyl origin, Fletcher (1994) [29] was referred and concluded that the annual effective dose for inhalation of ${ }^{137} \mathrm{Cs}$ was estimated to be $7.44 \mathrm{nSv} \mathrm{y}^{-1}$ with the ${ }^{137} \mathrm{Cs}$ content in tobacco leaves averaging to $40 \mathrm{~Bq} \mathrm{~kg}^{-1}$, in Libya and annual intake $1 \mathrm{~Bq} \mathrm{y}^{-1}$ for ${ }^{137} \mathrm{Cs}$.

\section{Conclusions}

The radioactivity in tobacco leaves collected from 15 different regions of Greece before cigarette production has been studied in order to find any association between the uptake of the naturally occurring primordial radionuclides and the radioisotopes of cesium of Chernobyl origin. The activities of the radioisotopes of radium, ${ }^{226} \mathrm{Ra}$ and ${ }^{228} \mathrm{Ra}$ in the tobacco leaves would be either through root 
uptake or through the fertilizers used for cultivation of tobacco plants in the fields, as the air concentrations of the radioisotopes of radium are extremely low. Lead-210 originating from air was deposited onto the tobacco leaves and trapped by the trichomes. Potassium-40 in the tobacco leaves was due to root uptake either from soils or from fertilizers. The radioisotopes of cesium, ${ }^{137} \mathrm{Cs}$ and ${ }^{134} \mathrm{Cs}$, in the tobacco leaves were due to root uptake and not to deposition onto the leaf foliage as they still remained in soil four years after the Chernobyl reactor accident but were absent from the atmosphere because of the rain washout (precipitation) and gravitational settling.

In estimating the radiation dose induced from smoking, it was concluded that the annual effective dose to lungs due to inhalation for adults (smokers) averaged to $80 \mu \mathrm{Sv}$ for ${ }^{226} \mathrm{Ra}, 67 \mu \mathrm{Sv}$ for ${ }^{228} \mathrm{Ra}$ and $105 \mu \mathrm{Sv}$ for ${ }^{210} \mathrm{~Pb}$, that is $252 \mu \mathrm{Sv}$ in total. The annual effective dose due to ${ }^{137} \mathrm{Cs}$ of Chernobyl origin averaged to about $200 \mathrm{nSv}$, that is three orders of magnitude lower than that of the naturally occurring radionuclides. The effective dose of $252 \mu \mathrm{Sv}$ per year must be compared with the average worldwide exposure to natural radiation sources due to inhalation $1.26 \mathrm{mSv} \mathrm{y}^{-1}$.

\section{References}

1. Martell, E.A. Radioactivity of tobacco trichomes and insoluble cigarette smoke particles. Nature 1974, 249, 215-217.

2. Tso, T.C.; Harley, N.; Alexander, L.T. Source of lead-210 and polonium-210 in tobacco. Science 1966, 153, 880-882.

3. Francis, C.W.M.; Chesters, G.; Erhardt, W.E. ${ }^{210}$ Polonium entry into plants. Environ. Sci. Technol. 1968, 2, 690-695.

4. Chakraborty, M.K.; Weybrew, J.A. Tobacco Sci. 1963, 7, 122 as cited in Nature 1974, 249, 215 217.

5. Barrera, R.; Werusman, E.W. Tobacco Sci. 1966, 10, 157 as cited in Nature 1974, 249, 215-217.

6. Papastefanou, C. Radiological impact from atmospheric releases ${ }^{f}{ }^{f 38} U$ an ${ }^{\mathrm{d} 226} \mathrm{Ra}$ from phosphate rock processing plants. J. Environ. Radioactivity 2001, 54, 75-83.

7. Papastefanou, C.; Bondietti, E.A. Mean residence times of atmospheric aerosols in the boundary layer as determined from ${ }^{210} \mathrm{Bi} /{ }^{210} \mathrm{~Pb}$ activity ratios. J. Aerosol Sci. 1991, 22, 927-931.

8. Papastefanou, C.; Manolopoulou, M.; Charalambous, S. Radiation measurements and radioecological aspects of fallout from the Chernobyl reactor accident. J. Environ. Radioactivity 1988, 7, 49-64.

9. Martell, E.A. Radioactivity in cigarette smoke. N. Engl. J. Med. 1982, 307, 309-313.

10. Martell, E.A.; Sweder, K.S. The roles of polonium isotopes in the etiology of the lung cancer in cigarette smokers and uranium miners. In Proceedings of the International Conference on Radiation Hazards in Mining, USA, 4-9 October 1981; Gomez. M., Ed.; Colorado School of Mines: Golden, CO, (AIME: NY) 1982; pp. 383-389.

11. Martell, E.A. Tobacco radioactivity and cancer in smokers. Am. Sci. 1975, 63, 404-412.

12. Martell, E.A.; Sweder, K.S. Properties of radon progeny aerosols in mainstream cigarette smoke and the alpha dose at segmental bifurcations of smokers. In Proceedings of Radiation Research Society Special Workshop on Current Topics in Lung Dosimetry, Salt Lake City, Utah, 21-22 April 1982; US. Government Printing Office: Washington D.C., 1983; pp. 144-151. 
13. Radford, E.P. Jr.; Hunt, V.R. Polonium-210: A volatile radioelement in cigarette. Science 1964, 143, 247-249.

14. Winters, T.H.; Di Franza, J.R. Radioactivity in cigarette smoking. N. Engl. J. Med. 1982, 306, 364-365.

15. Takizawa, Y.; Zhang, L.; Zhao, L. ${ }^{210} \mathrm{~Pb}$ and ${ }^{210} \mathrm{Po}$ in tobacco- with a special focus on estimating the doses to man. J. Radioanal. Nucl. Chem. Articles 1994, 182, 119-125.

16. Peres, A.C.; Hiromoto, G. Evaluation of ${ }^{210} \mathrm{~Pb}$ and ${ }^{210} \mathrm{Po}$ in cigarette tobacco produced in Brazil. $J$. Environ. Radioactivity 2002, 62, 115-119.

17. Colangelo, C.H.; Huguet, M.R.; Palacios, M.A.; Oliveira, A.A. Levels of ${ }^{210} \mathrm{Po}$ in some beverages and in tobacco. J. Radioanal. Nucl. Chem. Lett. 1992, 166, 195-202.

18. Khater, A.E. Polonium-210 budget in cigarettes. J. Environ. Radioactivity 2004, 71, 33-41.

19. Eisenbud, M.; Gesell, T. Environmental Radioactivity, $4^{\text {th }}$ Ed.; Academic Press: San Diego, USA, 1997.

20. Kelley, T.F. Polonium-210 content of mainstream cigarette smoke. Science 1965, 149, 537-538.

21. Holtzman, R.B.; Ilcewicz, F.H. Lead-210 and polonium-210 in tissues of cigarette smokers. Science 1966, 153, 1259-1260.

22. Manolopoulou, M. A radioecological study of the coal power plant environment. Ph.D. Thesis. Aristotle University of Thessaloniki: Thessaloniki, Greece, 1990; p.178.

23. UNSCEAR United Nations Scientific Committee on the Effects of Atomic Radiation. Sources and Effects of Ionizing Radiation. UNSCEAR: New York, NY, USA, 2000.

24. Papastefanou, C.; Manolopoulou, M.; Stoulos, S.; Ioannidou, A. Behavior of ${ }^{137} \mathrm{Cs}$ in the environment one decade after Chernobyl. J. Radioecology 1996, 4, 9-14.

25. NRPB. National Radiological Protection Board. Committed equivalent organ doses and committed effective doses from intakes of radionuclides. NRPB Report M. Chilton, Didcot, UK, 1991; p. 288.

26. UNSCEAR United Nations Scientific Committee on the Effects of Atomic Radiation. Sources and Effects of Ionizing Radiation. UNSCEAR: New York, NY, USA, 1993.

27. ICRP. International Commission on Radiological Protection. Age-dependent doses to members of the public from intake of radionuclides. Part 5: Compilation of ingestion and inhalation dose coefficients. ICRP Publication 72. Pergamon Press: Oxford, UK, 1996.

28. EC. European Commission. Investigation of a possible basis for a common approach with regard to the restoration of areas affected by lasting radiation exposure as a result of past or old practice or work activity. In CARE Final Report. Vandenhove, H., Bousher, A., Jensen, P.H., Jackson, D., Lambers, B., Zeevaert,T., Eds. European Commission DG XI Environment, Nuclear Safety and Civil Protection, under contract 96-ET-006, Brussels, Belgium, 1999.

29. Fletcher, J.J. Doses from radiocesium and ${ }^{40} \mathrm{~K}$ activities found in some tobacco leaves and cigarettes. Appl. Radiat. Isot. 1994, 45, 133-134.

(C) 2009 by the authors; licensee Molecular Diversity Preservation International, Basel, Switzerland. This article is an open-access article distributed under the terms and conditions of the Creative Commons Attribution license (http://creativecommons.org/licenses/by/3.0/). 